\title{
Medicalization, Demedicalization and Beyond: Antisocial Behaviour and the Case of the Dutch Youth Law
}

Citation for published version (APA):

Horstkötter, D., Dondorp, W., \& de Wert, G. (2015). Medicalization, Demedicalization and Beyond: Antisocial Behaviour and the Case of the Dutch Youth Law. Public Health Ethics, 8(3), 284-294. https://doi.org/10.1093/phe/phv018

Document status and date:

Published: 01/11/2015

DOI:

10.1093/phe/phv018

Document Version:

Publisher's PDF, also known as Version of record

Document license:

Taverne

Please check the document version of this publication:

- A submitted manuscript is the version of the article upon submission and before peer-review. There can be important differences between the submitted version and the official published version of record.

People interested in the research are advised to contact the author for the final version of the publication, or visit the DOI to the publisher's website.

- The final author version and the galley proof are versions of the publication after peer review.

- The final published version features the final layout of the paper including the volume, issue and page numbers.

Link to publication

\footnotetext{
General rights rights.

- You may freely distribute the URL identifying the publication in the public portal. please follow below link for the End User Agreement:

www.umlib.nl/taverne-license

Take down policy

If you believe that this document breaches copyright please contact us at:

repository@maastrichtuniversity.nl

providing details and we will investigate your claim.
}

Copyright and moral rights for the publications made accessible in the public portal are retained by the authors and/or other copyright owners and it is a condition of accessing publications that users recognise and abide by the legal requirements associated with these

- Users may download and print one copy of any publication from the public portal for the purpose of private study or research.

- You may not further distribute the material or use it for any profit-making activity or commercial gain

If the publication is distributed under the terms of Article $25 \mathrm{fa}$ of the Dutch Copyright Act, indicated by the "Taverne" license above, 


\title{
Medicalization, Demedicalization and Beyond: Antisocial Behaviour and the Case of the Dutch Youth Law
}

\author{
Dorothee Horstkötter*, Department of Health, Ethics and Society, CAPHRI, \\ Maastricht University \\ Wybo Dondorp, Department of Health, Ethics and Society, CAPHRI, Maastricht \\ University \\ Guido de Wert, Department of Health, Ethics and Society, CAPHRI, Maastricht \\ University
}

*Corresponding author: Dorothee Horstkötter, Department of Health, Ethics and Society, CAPHRI, Maastricht University, Postbox 616, 6200 MD,
Maastricht, The Netherlands. Tel.: 0031-43-3881144; Fax: 0031-43-3670932; Email: d.horstkoetter@maastrichtuniversity.nl

Youth antisocial behaviour (ASB) is frequently considered to be displayed by children and adolescents who suffer from behavioural disorders. Consequently, attempts to reduce ASB have increasingly comprised mental health interventions. Moreover, early signalling of children at risk and early prevention of behavioural problems are regarded as crucial remedies. Critical investigations of these developments, however, are in particular concerned with the consequent medicalization of society and the behaviour exhibited by infants, children and adolescents. Consequently, the new Dutch youth law even refers to demedicalization as a central aim. From an ethical point of view, this article critically discusses the meaning and relevance of the medicalization reproach in the context of ASB. The aim is to show that the term medicalization (M) can reasonably be attached to three different developments: the biomedical turn (M1), an increase in (forensic) youth mental health care (M2) and early signalling and prevention (M3). The ethical implications of these developments, however, are diverse, referring to both risks and benefits. By itself, neither the term medicalization nor demedicalization carries a self-evident normative meaning. Therefore, a careful ethical analysis is needed to reveal which social developments are actually recommendable or disadvantageous.

\section{Introduction}

Behavioural problems in children and adolescents elicit not only parental but also wider public concern. These concerns involve disruption of social and emotional development, as well as (serious) incidents of antisocial behaviour (ASB), juvenile delinquency and youth crime. The apparent attention to such developmental problems goes together with an increasing emphasis on the need for early identification and prevention and for effective treatment. As a consequence, more and more children are eligible for, or in need of, behavioural treatment and are seen by a variety of therapists and child mental health specialists. Currently, the prevention paradigm has been boosted by recent biomedical research that points towards the relevance of various genetic, neurobiological and physiological features, leading to sometimes far-reaching hopes and expectations regarding the development of better means of early identification, prevention and intervention in the foreseeable future. These developments could have important public health implications. In so far as population-wide prevention measures are proposed, ASB prevention involves large segments of society. Yet, this also applies to selective prevention that targets children who are considered at risk. It could be argued that not only is their own condition at stake, but also the wellbeing of the wider public. After all, depending on the availability and effectiveness of ASB prevention, third parties may cease to become victims of (later) ASB.

While early signalling and prevention are often considered effective remedies against behavioural problems in children and adolescents, there are also serious concerns regarding the potential ethical and social consequences. 
First of all, the focus is on the individual rather than on social factors. As a consequence, the behaviour exhibited by infants, children and juveniles has become increasingly medicalized (Verweij, 1999; Conrad, 2007; Aho, 2008; Carpenter-Song, 2009; Kvaale et al., 2013): Behavioural patterns that previously were considered annoying, yet typical, occurrences of growing-up and daily life, are now seen through medical glasses, i.e. classified in medical terms, and approached by mental health strategies.

In this regard, a recent youth policy development in the Netherlands is an interesting example. The so-called 'transition in youth care' is not only characterized by large-scale administrative decentralization, but is also defended as an allegedly necessary contribution to the demedicalization of the care for young people. In its critique of the previous system, the Dutch government stressed that this would unnecessarily medicalize deviant behaviour (Ministerie van Volksgezondheid Welzijn en Sport and Ministerie van Veiligheid en Justitie, 2013: 2). Even though this implies that there are also cases in which medicalization is actually necessary and justified, generally speaking, medicalization seems to be a problem and demedicalization is considered to be its solution. Thus, the Dutch government not only applies the respective concepts of medicalization and demedicalization rather loosely, but it also presumes and acts on particular normative assumptions referring to medicalization as a self-evident problem and demedicalization as the corresponding solution.

This article explores concerns about youngsters with behavioural problems and considers whether these are aptly expressed in terms of medicalization. Focusing on the example of 'antisocial behaviour', it will be argued that even though conduct associated with this kind of behaviour can reasonably be approached in non-medical terms, a general 'medicalization reproach' obscures rather than clarifies the many ethical issues that arise in the highly dynamic field of care for youngsters with behavioural problems. The normative argument does not follow inevitably from the mere description. To develop this argument, this article first presents briefly the example of the Dutch 'transition in youth care' and highlights relevant arguments made both in favour and against the underlying law. Secondly, an analysis of three different processes that can reasonably be attached to the concept of 'medicalization' in debates regarding the development and handling of ASB is presented. Thirdly, the article reflects on the issues and arguments behind these respective developments from an ethical point of view. Finally, it reconsiders the promises and the value of 'demedicalization' and reflects upon the question of which developments can be covered by this term and whether these may, or may not, deal with the apparent ethical issues emphasized by the medicalization reproach.

Frequently, the concept of ASB is criticized as being underdefined and vague (Sadler, 2008; Pickersgill, 2009, 2012). Although we cannot solve this problem here, we would like to make clear that we employ a rather broad understanding of the term 'antisocial behaviour'. It refers to types of behaviour that cause significant harm to others and self, as well as to personality features that may render such behaviours likely (Horstkötter et al., 2014a). This, however, does not imply any assumption about the ultimate source(s) of these behaviours or features. These may be individual, social or, most probably, a combination of both.

\section{An Example from the Netherlands: The Transition of Youth Mental Health Care}

The Dutch government has recently restructured large parts of its care facilities, including the youth care system (Bosscher, 2014). Thereby, it wanted to 'turn the tide of medicalization' and instead 'facilitate and stimulate the ability to cope by oneself' (Ministerie van Volksgezondheid Welzijn en Sport and Ministerie van Veiligheid en Justitie, 2013: 6). In other words, the government's aim is demedicalization by transferring responsibility from medical doctors and other professionals to the individuals involved [normaliseren, ontzorgen en demedicaliseren]. Reflections on this actual example are of great heuristic value to the general debate on the ethical evaluation of medicalization and demedicalization for public health purposes.

The law on youth care is an important example in this regard. It was recently passed by the Dutch Parliament (Eerste Kamer der Staten General, 2014) and regulates that from 2015 onwards, the organization and issues of the youth care systems have changed fundamentally. Municipalities now have sole responsibility for both the organization and funding of all kinds of youth care. The law further indicates several starting points for future policies which mainly cover prevention and early signalling of behavioural problems, demedicalization and the provision of integral care to families. Demedicalization, in turn, is said to be achieved through a variety of measures such as the strengthening of the educational climate in families and the furthering of children's social environment, by promoting the educational capacities of parents and by introducing own problem-solving abilities [eigen kracht] before 
professionals and public care facilities are contacted. Hence, more emphasis is placed on care for 'normal' children and on more and earlier prevention of behavioural disturbances (Ministerie van Volksgezondheid Welzijn en Sport and Ministerie van Veiligheid en Justitie, 2013: 13). This national policy measure will comprise general youth care, as well as youth mental health care. The intention is that the care for youth itself will become better, and in cases where various forms of care are provided these will be better coordinated.

This law has inspired heated debates amongst professionals and citizens affected by it. A particular concern is that not only general youth care but also the youth mental health care system will be part of the transition in youth care (Petitie Jeugdggz, 2014). Proponents of this addition argue that particularly the integration of the youth mental health care system in this process contributes to the envisaged demedicalization. Today, many less severe cases are treated in a costly and highly specialized system, while they may, in fact, be better dealt with elsewhere. Many psychological problems in children and adolescents should not be considered in medical terms, but could be the consequences of a variety of adverse social and educational factors like poverty or an overburdening school system (Batstra, 2013) or are simply typical, yet annoying, phases of normal growing up, making medical approaches unnecessary. As P. Heijnen, who as a politician initiated the youth law, states: 'You and I can do that as well, so to speak' (Levy, 2013, min 20.25). Opponents of the integration of the youth mental health care into the youth law, however, are concerned that access and right to this kind of care will be at stake, because this process implies that the youth mental health care system is separated from the rest of the health care system (Nederlandse Vereniging voor Psychiatrie et al., 2014). In line with this, this kind of care is no longer named 'youth mental health care', but instead is termed 'specialized youth care'. Furthermore, some are alarmed that policy makers and local politicians might fail to understand the complex nature of (forensic) mental health problems and the fact that children may already have such problems that require specialized mental health care, i.e. medical treatment (Wigersma, 2013). The proposed demedicalization will then not only target the less severe cases, but also the very serious cases. In other words, not only will cases in which current 'medicalization' is considered unnecessary be affected, but also cases for which there is widespread agreement that they should count as posing a genuine medical problem. Moreover, the concern is that non-experts will get involved into such distinctions and at least co-determine whether anybody counts as a severe case and requires specialized youth care. Improper reasons, e.g. financial restrictions, may further influence such decisions. As a result, children with serious mental health problems may no longer be recognized as having such problems and therefore can experience significant difficulties in receiving the right type of care.

\section{Medicalization Disentangled}

The crucial question is whether reference to demedicalization actually will solve problems apparently attached to processes of medicalization. To this end, a proper understanding of these concepts is essential. The concept of medicalization has its roots in sociology. Historically, it first and foremost highlighted the abuse of power by doctors, pharmaceutical agencies and the entire medical system and the resulting suppression of patients, particularly, mental health patients (Chodoff, 2002; Nye, 2003). More recently, the term of medicalization has been used to describe the changing relationships in the medical system where people, despite being healthy, seem to be increasingly eager and willing to receive a huge share of - preventive-health care and to participate in many health care interventions (Devisch and van Hoyweghen, 2011). Essentially, more and more aspects of human life are understood in terms of health and illness and considered to belong to the competence of the medical profession (Nye, 2003).

Policy measurements like the Dutch youth law are presented as justified due to demedicalization. Consequently, a simultaneous explicit case against medicalization is made: Medicalization is undesirable and should be stopped. This may be achieved by facilitating processes that operate outside the medical domain, hence contributing to demedicalization. Apparently, in this case the term medicalization is used in a hybrid sense. It does not only describe a certain situation, it also evaluates and, typically, depreciates it. Focusing on the normative side, however, the question arises, why is medicalization undesirable? According to the initial deployment of the term, this seems to be true by definition. Nonetheless, one may wonder whether this is apt and whether the morally relevant aspects receive reasonable attention. That is, even though it seems possible to define medicalization so that it exclusively covers negative and despicable developments and to reserve the term demedicalization for valuable aims, in addition it seems necessary to develop arguments to this avail. First of all, this requires an analysis of the meaning of medicalization. As the following shows, 
the concept can refer to three different developments, each with its own morally relevant aspects to be discussed afterwards.

Firstly, there is an increasing interest in the potential biological foundations of ASB. This covers a variety of aspects ranging from genetic polymorphisms, to structural and functional deviations in the brain and aberrations in psycho-physiological responses to stress. These features have been considered to be different in people with or without behavioural disorders and those who either have or have not exhibited some kind of ASB. Heritability studies, for example, aim to point out the relative share of genetics as opposed to environmental factors in the causation of behaviour (Baker et al., 2009), while molecular genetic studies aim to identify gene sequences that regulate neurotransmitters (e.g., serotonin or cortisol) considered relevant to behavioural disorders like conduct disorder $(\mathrm{CD})$ or attention-deficit-hyperactivity disorder (ADHD) (Comings, 2000), which, in turn, are frequently linked to ASB. Often, such studies point towards the relevance of gene-environment interactions (Caspi et al., 2002; Moffitt, 2005). Brain imaging research aims to identify deviations in brain structure and function and focuses on brain systems involved in emotion regulation, the processing of social information, goal-directed behaviour and inhibitory control (Shirtcliff et al., 2009). Furthermore, as regards neurophysiology and neuroendocrinology, children with behavioural disorders have been considered to display a lower resting heartbeat and lower skin conductance, indicating that their stress regulation and fear experience may be disturbed (van Goozen and Fairchild, 2009). As they study the potential biological origins of ASB, such research approaches and findings may lead to clinical applications and thereby contribute to the medicalization of ASB.

Secondly, the concept of medicalization is relevant in the area of juvenile delinquency and youth justice. Even though crimes committed by juveniles typically result in public outcries with much and predominantly negative public and media attention, professionals working with these juveniles frequently point to the often substantial behavioural disorders from which these youngsters suffer (Colins et al., 2010). This also applies to juveniles whose harmful behaviour is first and foremost noticed by schools, recreational facilities like sports clubs or at home by parents. Frequently, such children and juveniles are referred to mental health institutions. Correspondingly, it is argued that standardized mental health screening at detention intake, should be in place for cases where it is needed. For the most serious cases, judges in the Netherlands have the option of imposing a so-called PIJ-order (Placement in an Institution for Juveniles) which means that they can force juvenile offenders to undergo treatment for a behavioural disturbance or mental disorder (van Marle et al., 2010). Without these ambitions, the harmful, or otherwise seriously disturbing, behaviour in question may have been mainly, if not solely, considered in either educational, punitive or judicial terms. Therefore, the attention currently paid to the mental health condition of these young people can be described as a process of medicalization. ${ }^{1}$ Provided most mental health problems are considered to be related to both social-psychological and biomedical features, this understanding of medicalization is different from the one described previously. Nonetheless, the borders are evidently not clear-cut. Also biomedical research increasingly acknowledges the relevance of gene-brain-environment interaction.

Thirdly, the call for prevention of ASB has been increasingly insistent (Farrington and Welsh, 2007; Loeber et al., 2008). Typically, prevention is considered most effective if applied as early in life as possible and preferably before children develop their first behavioural problems (Farrington and Welsh, 2007). In this regard, it has been argued that preventive measures should not only cover young children with first behavioural syndromes or even early police contacts, but also infants and (not yet born) babies who do not-yetexhibit behavioural problems (Tremblay, 2010). Thereby, ASB prevention may not only become an important public health topic that targets large portions of the population but also aims at reducing victimization and increasing feelings of public safety. Moreover, the emphasis on early signalling and prevention entails a process of medicalization in two respects.

On the one hand, early signalling of children considered at risk of developing ASB and early ASB prevention that targets asymptomatic children can turn young children who have not yet exhibited any behavioural problems into proto-patients (Verweij, 1999). Thereby, early prevention creates patients, or mental health consumers, before there is an actual mental health care need and in situations where such a need may never develop. In line with this consideration, behavioural interventions have been described as 'behavioural vaccines' (Embry, 2002); just like vaccinations against viral infections, these interventions should render children immune to all kinds of influences that could result in the development of behavioural disorders and subsequent ASB. On the other hand, early preventive interventions may involve children whose behaviour is already attracting some kind of negative attention or concern. As long as this attention is 
expressed in social or educational terms or even in cases where children are punished for bad behaviour, medical terms do not apply. Yet, as soon as these behaviours are considered, for example, to be the manifestation of some kind of mental health problem like CD or ADHD, these behaviours can be considered to be medicalized. For children with less severe behavioural disturbances, such descriptions are likely to make a tremendous difference. Adverse social circumstances that cause 'bad' behaviour may be overlooked and social remedies could be neglected. Moreover, their problems may be temporary, in the sense that they may simply outgrow them. A focus on early ASB prevention may also bring many of them to light, while a focus on treatment of established serious instances of behavioural troubles could leave these children unnoticed and undisturbed by the mental health system.

Thus, regarding juvenile ASB, medicalization (M) can refer to three different processes: First of all, the understanding of behaviour as mainly caused by various biological features (M1), secondly, the identification of harmful or offending behaviour as being largely due to mental disorders (M2) and the application of public health measures to safeguard the development of 'normal' behaviour and prevent the onset of behavioural disorders (M3). This manifold denotation of the concept of medicalization renders Rose's critique of the term both applicable and convincing. He stated that it would 'obscure the differences between placing something under the sign of public health [resembling M3], [...], placing something under the authority of doctors to prescribe [...] a disease [resembling M2], [...] and placing something within the field of molecular psychopharmacology [resembling M1]' (Rose, 2007: 701). Moreover, by implication, the term demedicalization (DM) can also refer to three different developments in this context. It may entail the rejection of, or reduced attention towards, biomedical approaches and hence increased, or exclusive, emphasis on social causes (DM1). It may also lead to a renewed focus on educational, social or punitive approaches to juvenile delinquents with no or less involvement of-forensic—child and adolescent psychiatrists and psychologists (DM2). Finally, it may mean the reduction of early preventive efforts regarding 'normal' behaviour and asymptomatic and less severe cases in favour of the treatment of established serious behavioural problems (DM3) [cf. Table 1 for an overview].

This complexity is not only theoretical, but also has practical consequences for the credibility and persuasive power of policy measures that reject medicalization and instead rely on demedicalization. This is particularly problematic if the apparent faults with medicalization are merely assumed rather than argued for, and if only one aspect of medicalization is referred to while other relevant developments are ignored. Evidently, the example of the Dutch youth law entails such problems. It refers solely to the concern that currently (too) many doctors are involved in the care for children with (too mild) behavioural problems and (too) many young people are considered to have a behavioural disorder. As a consequence, its understanding of demedicalization covers mainly the aim that fewer children and adolescents should be medically diagnosed and treated by mental health professionals. Even if proven correct that too many children receive mental health diagnoses, many of them unjustified, this focus on the meaning of demedicalization can still be said to be not only onesided, but also to allow for and even provoke developments that can be characterized as contributing to further medicalization. The law's silence on current developments in biomedical research can be interpreted as an implicit acceptance of potential future biomedically informed applications (M1). More seriously, however, it explicitly announces an intensified focus on early signalling and prevention. However, in so far as early prevention can be said to intensify rather than reduce medicalization (M3), the relationship between the youth law and demedicalization becomes highly confusing. By way of reply one could argue that successful early prevention may reduce the need for later mental health care in juveniles and young adults. Irrespective of whether this assumption is correct or not, such a reply explicates the fact that there may be a conflict between medicalization now (early prevention in children, M3) and demedicalization later on (no or less need for mental health interventions in adolescents, DM2). Therefore, from the outset it is unclear which measures, and why, should or should not, count as being part of the medical domain. This confusion also arises with regard to the role of the professionals involved. For example, remedial educationalists [orthopedagogen] selfevidently have a remedial and an educationalist task. When evaluating the role of this profession, however, one can focus on the remedial task and argue that these professionals in particular contribute to the medicalization of child-rearing (Winter, 2013). By contrast, however, one can likewise focus on the educational mission and argue that the assignment of exactly this profession may underscore the demedicalizing potential of prevention: It is something that educationalists do rather than doctors or nurses (Van Yperen, 2013). The Dutch law's focus on both prevention and demedicalization carries this conceptual confusion to extremes. 
Table 1. Overview of the developments that medicalization and demedicalization can refer to

\begin{tabular}{|c|c|c|c|c|c|}
\hline \multicolumn{2}{|c|}{ Development related to: } & \multicolumn{2}{|l|}{ Medicalization (M) } & \multicolumn{2}{|l|}{ Demedicalization (DM) } \\
\hline 1 & $\begin{array}{c}\text { Causes and } \\
\text { remedies }\end{array}$ & $\begin{array}{l}\text { Biological features, } \\
\text { (future) biomedical } \\
\text { applications }\end{array}$ & M1 & $\begin{array}{l}\text { Social and environmental } \\
\text { risk factors }\end{array}$ & DM1 \\
\hline & & & & Psychosocial practices & \\
\hline 2 & $\begin{array}{l}\text { Concepts and } \\
\text { authority }\end{array}$ & $\begin{array}{l}\text { Mental disorder dealt } \\
\text { with by mental health } \\
\text { professional }\end{array}$ & M2 & $\begin{array}{l}\text { Educational, social or moral } \\
\text { problem dealt with by } \\
\text { (professional) educators } \\
\text { Attention for diversity }\end{array}$ & DM2 \\
\hline 3 & $\begin{array}{l}\text { Point in time } \\
\text { and stage of } \\
\text { the problem }\end{array}$ & $\begin{array}{l}\text { Early signalling and pre- } \\
\text { vention, focus on } \\
\text { asymptomatic cases } \\
\text { and initial problems }\end{array}$ & M3 & $\begin{array}{l}\text { Reduced prevention, focus } \\
\text { on dealing with / treat- } \\
\text { ment of established be- } \\
\text { havioural problems }\end{array}$ & DM3 \\
\hline
\end{tabular}

In summary, (i) the term medicalization can refer to various developments which, however, are seldom explicated, (ii) it is frequently assumed to refer to dreadful developments while no arguments are provided to this avail and (iii) often it is not clear what is and what is not part of the medical domain because the borders between the medical and the non-medical are blurring. It is for these reasons that the morally relevant aspects of the various processes described cannot be assessed by describing them as contributing to, or being part of, either medicalization or demedicalization.

\section{Ethical Analysis: To Medicalize or to Demedicalize, That is Not the Question}

To this end, an ethical analysis is needed to address each of the three identified developments. As mentioned, we realize that the various developments are interconnected. However, for the sake of conceptual clarity, they are separated in the following ethical analysis and discussed in an 'ideal-typical' manner. The developments discussed are the biomedical turn, forensic adolescent mental health care and the prevention paradigm. Here, key aspects will be highlighted, and thereby, it will be pointed out that ethically neither medicalization nor demedicalization by itself is either prudent or reprehensible.

\section{Ethical Aspects of the Biomedical Turn}

Scientific attention to biological features of human behaviour in general and ASB in particular raised controversy from the outset (Roush, 1995). Sceptics pointed towards a series of potential ethical, social and legal implications. (Andrews, 1999; Wasserman and Wachbroit, 2001; Nuffield Council on Bioethics, 2002; Parens et al. 2006; Singh and Rose, 2009). Even though discussions in this regard typically focused on adults, most concerns presented were also applicable to young people and the (early) prevention of ASB (Horstkötter et al., 2014b; Singh and Rose, 2009).

A fundamental concern pertains to the reductionist potential of biological approaches. Such a perspective can lead to a biased focus on the individual and medical features, thereby ignoring social and environmental factors. This, in turn, may imply a series of ethical drawbacks. Children identified as being at risk of developing ASB or who have committed some offence may face being labelled, stigmatized or discriminated against because of their genetic and/or neurobiological make-up. As a consequence, they could assume a deterministic stance, adopt a fatalistic attitude, or perceive their behaviour as being caused externally ('My brain/genes did it') and deny responsibility (Levitt and Manson, 2007). In this connection, the identity development of young people may be affected negatively so that they perceive themselves as being fundamentally different or essentially antisocial ('I am a born criminal'). The danger of a self-fulfilling prophecy lurks: Young people adapt their behaviour to their biomedically underpinned risk-status. Finally, a biomedical approach may lead to an increase in psychopharmacological prescriptions, implying the danger of negative side effects. In so far as these concerns are convincing, they constitute a strong argument against attention to biological features of human behaviour and biomedical applications regarding early identification, prevention and treatment that are based hereupon. 
This leads to the question whether the adoption of a largely psycho-social approach without biological findings and biomedical applications, and hence demedicalized in the sense of the first development identified (DM1), could reliably avoid these problems. As argued elsewhere (Horstkötter et al., 2014a), this need not be the case. In principle, also psychosocial means of early ASB prevention can entail the same, or similar, ethical problems. The exposure of social and psychological riskfactors, for example, could have similar stigmatizing effects. Sometimes, prevention projects are intentionally implemented population-wide. One reason for this strategy is to avoid otherwise stigmatizing effects. If everybody is involved, nobody is singled out. This attitude, however, highlights the implicit recognition of such ethical troubles, also regarding non-biomedical approaches. Furthermore, the accentuation of apparent social risk factors may also negatively influence children's identity development or may invoke a fatalistic attitude and the rejection of responsibility ('My bad neighbourhood/childhood made me do it'). Therefore, DM1 need not imply ethical superiority. Moreover, frequently biomedical and environmental factors interact. In so far as these interactions are taken into account, the boundaries between biomedical and psychosocial approaches appear fundamentally blurred rather than neatly separated. Also for this reason, any polarity between medicalization (M1) and demedicalization (DM1) seems unable to adequately address complexities that are 'beyond the nature and nurture divide' (Singh, 2012). Rather than discussing the disciplinary background of any measure and whether it implies medicalization or demedicalization, it is necessary to discuss the actual ethical issues at stake.

\section{Ethical Aspects of Forensic Adolescent Mental Health Care}

M2 refers to the observation that frequently young people who exhibit harmful behaviour and juvenile delinquents are considered to suffer from some behavioural disturbance or mental disorder which influences their conduct or offence. Diagnosing young people in this way or even sentencing juvenile delinquents to undergo treatment, in effect, changes bad or criminal behaviour into a medical issue. The normative evaluation of this course of action, however, depends on a variety of aspects. In so far as a medical approach implies help for the youngster treated, reduces his or her risk of recidivism and contributes to his or her welfare in any other way, a medical approach may be more sensible than inappropriate. The crucial question is then: does framing delinquent behaviour in medical terms have positive consequences? Scientific studies (van Marle et al., 2010) point to such successes and suggest that also long-term behaviour and the well-being of those who undergo treatment is higher compared to their untreated peers. This, however, could still be rejected if one were to argue that such medical approaches merely treat outer symptoms while the actual social causes of the problems remain unchallenged. Also juveniles themselves seem to have rather mixed attitudes as to the overall value of a medical treatment approach. A series of interviews we conducted in a juvenile justice institution revealed that some appreciated the treatment provided as help to their development and hence, at least implicitly, recognized the positive value of the underlying medicalization (Horstkötter et al., 2012). Others, however, rejected such involvements as taking something of their personality away or considered it inappropriate and degrading to be described in medical or mental health terms. Instead, they were ready to accept that their behaviour and even their personality were described in moral terms (it was/they were bad or wrong) and were disapproved. This attitude allowed them to retain their dignity and self-identity.

Apparently, concerns regarding the medicalization of ASB in the sense of M2 have a point to some extent. It would be appropriate to focus on and change relevant social adversities. Likewise, it can be adequate to describe certain kinds of troublesome behaviour of young people and even youth criminal behaviour in moral rather than medical terms, and as a consequence, approach it as an educational or maybe judicial rather than a therapeutic challenge. This, however, does not constitute a general argument against M2 and in favour of DM2. A general rejection of M2 would imply, for example, that also voluntary requests for mental health investigation and potential treatments are hampered. This may even hold in cases where there is agreement about the seriousness of the mental problem or medically relevant influences, such as certain kinds of brain lesions or brain tumours. In such cases, a general DM2 approach could lead to situations in which young people are deliberately denied access to care or in which the right to a fair trial are restricted for juvenile suspects who genuinely suffer from a mental disorder.

This situation has also been called the 'paradox of lifestyle-policy' (Dehue, 2014). According to this analysis, people would first be considered responsible for their behaviour when they did not excuse or justify themselves or their children because of a disorder. 
Then, however, they would be left largely alone, as soon as they take their own responsibility and only look for help in case they realize they are unable to make the relevant changes themselves. In the framework of 'demedicalization', mental health may once again become more and more a matter of morality and merit, resulting in diagnoses having a bad image again. Nonetheless, people may try to do well in our complex and high-demanding societies and receive their medication without an official diagnosis and outside the medical framework.

Against this background, criticism of M2 can cover important risks and caveats. Yet, they do not comprise all morally relevant aspects. In particular, they are unable even to mention negative aspects that may go together with DM2.

\section{Ethical Aspects of Early ASB Prevention}

Medicalization does finally refer to an increased focus on prevention (M3). As mentioned, this can target two different groups: children considered at-risk who have not—yet—exhibited any kind of behavioural problems associated with ASB and children with initiating or established behavioural problems whose situation might or might not worsen further. With regard to the first group, the normative question is whether it is problematic if the focus on prevention turns them into medical cases before there is any actual need for medical help. With regard to the second group, the question is whether it is justifiable to consider their behaviour a medical rather than, for example, a social, educational or moral problem.

For both groups, much will depend on the question whether, and if so, to what extent, a medical approach serves their well-being and interests. In case parents are concerned about their child's (potential) behaviour and therefore ask a child psychologist or psychiatrist for help, according to the medical ethical principle of beneficence, it is an ethical requirement to answer such a request and provide the care considered appropriate. This holds irrespective of whether in previous times, medical professionals have also been involved. Nonetheless, in so far as mental health issues in general and ASB in particular are concerned, important complications may arise (Parens and Johnston, 2011). As argued, both biomedical, and psycho-social approaches can also have significant individual drawbacks. Mental health diagnoses regarding ASB may have serious stigmatizing effects. Therefore, and even despite a parental request for help, it may not be in the children's best interest to receive such a label, especially in cases where they are too young to realize such effects themselves. For these reasons, it remains a complex question whether and when mental health diagnoses are in the child's best interest. Most obviously this applies to asymptomatic children, as well as the less severe cases of children who may grow out of their problems by themselves and are not in need of specialized medical help. Yet, this may equally be true for the more serious cases. Recent attempts to differentiate a particularly serious subtype of children with the so-called 'callous-unemotional trait' (Rutter, 2012; Viding and McCrory, 2012) carries this worry to extremes. 'Can you call a 9-year-old a psychopath?' The question was recently asked in a news magazine (Kahn, 2012) and covers not only a scientific interest regarding whether such a diagnosis can reliably be made; it also covers fundamental ethical issues concerning the legitimacy of applying such severely negative terms to children. On the other hand, in case a child is already labelled because of his/her disruptive behaviour, a description of that behaviour in mental health terms may alleviate the moral burden and (partly) excuse the child and the parents. Furthermore, withholding mental health care may mean an end to taking children's mental health problems seriously and, as a consequence, contribute to an increased stigmatization of children and parents concerned. Rather than being mentally ill, children may (again) be considered naughty or terrific and parents may be regarded incapable of raising their children properly (Vermeiren, 2013). So, from an ethical point of view it is more important to determine which approach best serves the well-being and interests of a particular child, than whether, or not, it turns the child's behaviour into a medical case.

Finally, ASB causes harm not only to self but also to others. In so far as harm to self is concerned, the wellbeing and the best interest of the child itself should be taken into account. Even though it can be difficult to figure out how best to safeguard this interest, the aim as such is clear. The situation, however, is different if the potential harm to others is considered. Here a conflict may arise. In case an individual experiences drawbacks, while at the same time early ASB prevention effectively contributes to the reduction of harm to others and hence to social benefit, the question may arise whether, and if so when, this social benefit can justify the associated individual harm (Feinberg, 1985). Here, we cannot dwell on this issue in any great detail. However, we would like to emphasize that these are the kinds of questions that one has to consider when evaluating the value of early ASB prevention. In cases of conflict, should public safety interests or the individual 
interests of young people prevail? Against this background, the question whether or not prevention contributes to medicalization is of secondary importance. More seriously, if one were to reflect on the prevention paradigm in public health solely in terms of medicalization, one could easily overlook the very important difference between individual and public interests and thereby a core ethical dilemma.

\section{Demedicalization Revisited}

As the above analysis demonstrates, on all three accounts of medicalization possible ethical drawbacks are relevant and have to be considered. Yet, it becomes equally clear that the same may hold with regard to demedicalization. In none of the three developments distinguished can it be assumed that from an ethical point of view a demedicalizing account is to be preferred to a medical account. Both can be seen as having significant ethical drawbacks, as well as benefits. As a consequence, promoting demedicalization by way of justification, such as the Dutch government is currently doing, can only be a failing strategy. It is naive to assume that demedicalization as such is advantageous. Instead, attention should be paid to the various pros and cons of approaches that focus first and foremost on the conditions of 'normal' behaviour.

\section{Conclusion}

Whenever a social development is described in terms of medicalization, it is perceived as being the expression of a corresponding social and moral disapproval. Interestingly, the term medicalization is a hybrid one, being normative and descriptive at the same time. Unfortunately, when this inherent hybrid character is overlooked, the single term medicalization does not only refer to different developments, also it turns into a notion of moral condemnation that like 'violence' or 'discrimination' serves as an argument that seems to need no further justification. This, however, is wrong. The term medicalization refers to various developments, as does the supposed opposite of demedicalization. Each of these developments requires an ethical analysis of its own and clearly, each one contains a number of respective risks and benefits. Therefore, neither the term medicalization nor demedicalization should be invoked self-evidently in one specific normative sense. Instead, a careful ethical analysis should reveal which social developments are actually beneficial or not, regardless of whether they can be described as either medicalization or demedicalization.

\section{Funding}

This work was supported by ZonMw, the Netherlands Organisation for Health Research and Development [grant number 731010007].

\section{Conflict of Interest}

None declared.

\section{Note}

1. Judicial youth care, including PIJ-orders, will not be part of the new Dutch youth law. Nonetheless, discussing this form of care can elucidate a further development that is associated with the concept of medicalization. Furthermore, in many cases, judges have some leeway in deciding which kind of youth care (closed or judicial) to impose on a juvenile. Again, the boundaries of whether a juvenile will (in case he/she is sent to a closed youth care facility) or will not (in case he/she is sent to a judicial youth care facility) be targeted by the youth law are not clear-cut.

\section{References}

Aho, K. (2008). Medicalizing Mental Health: A Phenomenological Alternative. Journal of Medical Humanities, 29, 243-259.

Andrews, L. B. (1999). Predicting and Punishing Antisocial Acts: How the Criminal Justice System Might Use Behavioural Genetics. In Carson, R. A. and Rothstein, M. A. (eds), Behavioural Genetics. Baltimore, MD: Johns Hopkins University Press, pp. 166-155.

Baker, L. A., Bezdijan, S., and Raine, A. (2009). Behavioural Genetics: The Science of Antisocial Behaviour. In Farahany, N. A. (ed.), The Impact of Behavioural Sciences on Criminal Law. Oxford, UK: Oxford University Press, pp. 3-44.

Batstra, L. (2013). In het belang van onze kinderen [In Our Childrens' Interest], available from http://www.pdd-nos.nl/columns/2013 col/col_ dec_13.html [accessed 9 July 2015].

Bosscher, N. (2014). The Decentralisation and Transformation of the Dutch Youth Care System, available from http://www.youthpolicy.nl/yp/downloadsyp/ Publications-The-decentralisation-and-transformationof-the-Dutch-youth-care-system.pdf [accessed 9 July 2015]. 
Carpenter-Song, E. (2009). Caught in the Psychiatric Net: Meanings and Experiences of ADHD, Pediatric Bipolar Disorder and Mental Health Treatment Among a Diverse Group of Families in the United States. Culture, Medicine and Psychiatry, 33, 61-85.

Caspi, A., McClay, J., Moffitt, T. E., Mill, J., Martin, J., Craig, I. W., Taylor, A., and Poulton, R. (2002). Role of Genotype in the Cycle of Violence in Maltreated Children. Science, 297, 851-853.

Chodoff, P. (2002). The Medicalization of the Human Condition. Psychiatric Services, 53, 627-628.

Colins, O. Vermeiren, R., Vreugdenhil, C., van den Brink, W., Doreleijers, T. A. H., and Broekaert, E. (2010). Psychiatric Disorders in Detained Male Adolescents: A Systematic Literature Review. The Canadian Journal of Psychiatry, 55, 255-263.

Comings, D. E. (2000). The Role of Genetics in ADHD and Conduct Disorder-Relevance to the Treatment of Recidivistic Antisocial Behaviour. In Fishbein, D. H. (ed.), The Science, Treatment, and Prevention of Antisocial Behaviours: Application to the Criminal Justice System. Kingston, NJ: Civic Research Institute, pp. 16-11-16-25.

Conrad, P. (2007). The Medicalization of Society, on the Transformation of Human Conditions Into Treatable Disorders. Baltimore, MD: Johns Hopkins University Press.

Dehue, T. (2014). Betere mensen, Over gezondheid als keuze en koopwaar, [Better Humans, On Health as Choice and Trading Good]. Amsterdam, NL: Augustus.

Devisch, I. and van Hoyweghen, I. (2011). A New Era of Medical Consumption: Medicalisation Revisited. Aporia, 3, 16-21.

Eerste Kamer der Staten General. (2014). Eerste Kamer stemt in met nieuwe jeugdwet [First Chamber Approves Youth Law], available from http://www. eerstekamer.nl/nieuws/20140218/eerste_kamer_ stemt_in_met_nieuwe [accessed 9 July 2015].

Embry, D. D. (2002). The Good Behaviour Game: A Best Practice Candidate as a Universal Behavioural Vaccine. Clinical Child and Family Psychology Review, 5, 273-297.

Farrington, D. P. and Welsh, B. C. (2007). Saving Children from a Life of Crime, Early Risk Factors and Effective Interventions. Oxford, UK: Oxford University Press.

Feinberg, J. (1985). Offense to Others. Oxford: Oxford University Press.

Horstkötter, D., Berghmans, R., de Ruiter, C., Krumeich, A., and de Wert, G. (2012) 'We Are Also Normal Humans, You Know?' Views and Attitudes of Juvenile Delinquents on Antisocial Behavior,
Neurobiology and Prevention. International Journal of Law and Psychiatry, 35, 289-297.

Horstkötter, D., Berghmans, R., and de Wert, G. (2014b) Early Prevention of Antisocial Behaviour (ASB): A Comparative Ethical Analysis of Biomedical and Psychosocial Approaches. BioSocieties, 9, 60-83.

Horstkötter, D., Berghmans, R., Feron, F., and de Wert, G. (2014a) 'One Can Always Say No' Enriching the Bioethical Debate on Antisocial Behaviour, Neurobiology and Prevention: Views of Juvenile Delinquents. Bioethics, 28, 225-234.

Kahn, J. (11 May 2012). Can you Call a 9-year-old a Psychopath? New York Times Magazine, available from http://www.nytimes.com/2012/05/13/magazine/can-you-call-a-9-year-old-a-psychopath.html? pagewanted=all [accessed 13 May 2012].

Kvaale, E., Haslam, N., and Gottdiener, W. H. (2013). The 'side Effects' of Medicalization: A Meta-analytic Review of How Biogenetic Explanations Affect Stigma. Clinical Psychology Review, 33, 782-794.

Levitt, M., and Manson, N. C. (2007). My Genes Made Me Do It? The Implications of Behavioural Genetics for Responsibility and Blame. Health Care Analysis, $15,33-40$.

Levy, G.. (Director). (2 September 2013). Iedereen gaat het voelen: Geestelijke gezondheidszorg voor jongeren [Everybody Will Feel It: Mental Health Care for Juveniles]. Television: AVRO, Nederland 1. Available from http://www.npodoc.nl/speel.AVRO_1641086. html [accessed 9 July 2015].

Loeber, R., Slot, N. W., Van der Laan, P., and Hoeve, M. (Eds.). (2008). Tomorrow's Criminals. The Development of Child Delinquency and Effective Interventions. Surrey, UK: Ashgate.

Ministerie van Volksgezondheid Welzijn en Sport (VWS), and Ministerie van Veiligheid en Justitie (VJ). (2013). Memorie van toelichting bij de jeugdwet. [Explanatory Memorandum to the Youth Law], available from http://www.rijksoverheid.nl/documenten-en-publicaties/ kamerstukken/2013/07/01/memorie-van-toelichtingbij-de-jeugdwet.html [accessed 2 April 2014].

Moffitt, T. E. (2005). The New Look of Behavioural Genetics in Developmental Psychopathology: Geneenvironment Interplay in Antisocial Behaviour. Psychological Bulletin, 131, 533-554.

Nederlandse Vereniging voor Psychiatrie, Nederlands Instituut voor Psychologen, GGZNederland, and Landelijk Platform GGz. (10 February 2014). Persbericht: Kind met psychische aandoening verliest recht op zorg in nieuwe jeugdwet. [Press Release: Child with Mental Health Disorder Loses Right to Care in the New Youth Law], available 
from http://www.psynip.nl/index.php?p=1153315 [accessed 11 February 2014].

Nuffield Council on Bioethics. (2002). Genetics and Human Behaviour: The Ethical Context. London: Nuffield Council on Bioethics.

Nye, R. A. (2003). The Evolution of the Concept of Medicalization in the Late Twentieth Century. Journal of History of Behavioural Sciences, 39, 115-129.

Parens, E., Chapman, A. R., and Press, N. (Eds.). (2006). Wrestling with Behavioural Genetics, Science, Ethics and Public Conversation. Baltimore, MD: Johns Hopkins University.

Parens, E. and Johnston, J. (2011). Troubled Children: Diagnosing, Treating and Attending to Context, Special Report. The Hastings Center Report, 41, S1-S32.

Petitie Jeugdggz. (2014). Zorgen over de jeugd-ggz [Concerns about the Youth Mental Health Care System], available from www/petietiejeugdggz.nl [accessed 1 February 2014].

Pickersgill, M. (2009). NICE Guidelines, Clinical Practice and Antisocial Personality Disorder: The Ethical Implications of Ontological Uncertainty. Journal of Medical Ethics, 35, 668-671.

Pickersgill, M. (2012). Standardising Antisocial Personality Disorder: The Social Shaping of A Psychiatric Technology. Sociology of Health and Illness, 34, 544-559.

Rose, N. (2007). Beyond Medicalization. The Lancet, 369, 700-702.

Roush, W. (1995). Conflict Marks Crime Conference. Science, 269, 1808-1809.

Rutter, M. (2012). Psychopathy in Childhood: Is it a Meaningful Diagnosis? The British Journal of Psychiatry, 200, 175-176.

Sadler, J. Z. (2008). Vice and the Diagnostic Classification of Mental Disorders: A Philosophical Case Conference. Philosophy, Psychiatry and Psychology, 15, 1-17.

Shirtcliff, E. A., Vitacco, M. J., Graf, A. R., Gostisha, A. J., Merz, J. L., and Zahn-Waxler, C. (2009). Neurobiology of Empathy and Callousness: Implications for the Development of Antisocial Behaviour. Behavioural Sciences and the Law, 27, 137-171.

Singh, I. (2012). Human Development, Nature and Nurture: Working Beyond the Divide. BioSocieties, 7, 308-321.

Singh, I. and Rose, N. (2009). Biomarkers in Psychiatry. Nature, 460, 202-207.

Tremblay, R. E. (2010). Developmental Origins of Disruptive Behaviour Problems: The 'Original Sin'
Hypothesis, Epigenetics and their Consequences for Prevention. The Journal of Child Psychology and Psychiatry, 51, 341-367.

van Goozen, S. H. M. and Fairchild, G. (2009). The Neuroendocrinology of Antisocial Behaviour. In Hodgins, S. Viding, E. and Plodowski,A. (eds), The Neurobiological Basis of Violence: Science and Rehabilitation. Oxford, UK: Oxford University Press, pp. 201-221.

van Marle, H. J. C., Hempel, I. S., and Buck, N. M. L. (2010). Young Serious and Vulnerable Offenders in the Netherlands: A Cohort Follow-up Study After Completion of a PIJ (detention) Order. Criminal Behaviour and Mental Health, 20, 349-360.

Van Yperen, T. (2013). Gemeenten moeten zich realiseren dat kiezen voor een goedkoop aanbod dat onvoldoende effectief blijkt te zijn, in feite duurkoop is [Municipalities Should Realize that Chosing for a Cheap Offer that Turns Out Being Insufficiently Effective, in Fact is Very Expensive]. In Bakker, K., Kooijman, H. and Prakken, J. (eds), Om het kind, Visies op een ander jeugdstelsel. Utrecht, NL: Nederlands Jeugdinstituut, pp. 34-42.

Vermeiren, R. (2013). Om de problemen op te lossen, hebben we geen transitie nodig [To Solve the Problems, We do not Need the Transition]. In Bakker, K., Kooijman, H. and Prakken, J. (eds), Om het kind, Visies op een ander jeugdstelsel. Utrecht, NL: Nederlands Jeugdinstituut, pp. 44-50.

Verweij, M. (1999). Medicalization as a Moral Problem for Preventive Medicine. Bioethics, 13, 89113.

Viding, E. and McCrory, E. J. (2012). Why Should We Care About Measuring Callous-Unemotional Traits in Children? The British Journal of Psychiatry, 200, 177-178.

Wasserman, D. and Wachbroit, R. (eds) (2001). Genetics and Criminal Behaviour. Cambridge, UK: Cambridge University Press.

Wigersma, L. (20 August 2013). Jeugdwet: medische invalshoek zoek. [Youth Law: Medical Point of View Missing], available from http://knmg.artsennet.nl/ Dossiers-9/Columns/Column/135651/Jeugdwetmedische-invalshoek-zoek-1.htm [accessed 9 july 2015]

Winter, M. (2013). Door allerlei perverse prikkels worden problemen te makkelijk omgezet in diagnoses [Due to a Series of Perverse Triggers Problems are too Easily Converted into Diagnoses]. In Bakker, K., Kooijman, H., and Prakken, J. (eds), Om het kind, Visies op een ander jeugdstelsel. Utrecht: Nederlands Jeugdinstituut, pp. 9-15. 